\title{
Effects of Polymeric Zinc Propylen-Bis-Dithiocarbamate (Propineb) on Nasal Mucosa in Rats
}

\author{
Efectos de los Polímeros del Zinc Propileno-Bis-Ditiocarbamato \\ (Propineb) en la Mucosa Nasal de Ratas
}

\author{
Baver Samancı*; Eda Arslan**; Seyla Bolukbası Samancı***; Basak Caypınar ${ }^{* * * * *}$ \\ Engin Deveci $^{* * * * *}$; Sevda Söker ${ }^{* * * * *} \&$ Ugur Seker ${ }^{* * * * * *}$
}

SAMANCI, B.; ARSLAN, E.; SAMANCI, S. B.; CAYPINAR, B.; DEVECI, E.; SÖKER, S. \& SEKER, U. Effects of polymeric zinc propylen-bis-dithiocarbamate (propineb) on nasal mucosa in rats. Int. J. Morphol., 34(1):85-89, 2016.

SUMMARY: The objective of this study was to evaluate the histopathologic and immunohistochemical effects of propineb on rat nasal mucosa. Twenty adult Sprague-Dawley rats weighing 180-220 g, were used as experimental animals. The rats were divided into propineb and control groups. The control group received distilled water with spray at the same time period. The experiment was terminated after three weeks. In each case, sections of the nosewere taken. In experimental group, microscopic examination of nasal respiratory mucosa revealed that degenerative changes in epithelium were observed in sections of propineb-treated group. There were also leukocyte infiltration and vascular dilatation detected in the connective tissue. We detected CD34-immunoreactive mononuclear cells and endothel cells in the lamina propria of propineb group. In propineb group compared to the control group, the respiratory epithelium, goblet and basal cell nuclei were stained positive for PCNA. Propineb inhalation may be irritating to the nasal mucosa.

KEY WORDS: Propineb; Nasal mucosa; Proliferating Cell Nuclear Antigen (PCNA); CD34.

\section{INTRODUCTION}

Polymeric zinc propylen-bis-dithiocarbamate (Propineb) is a compound widely used in fruit and vegetables cultures due to its large spectrum of activity against fungal plant diseases. Previous repeated inhalation exposure studies in rats have shown two independent organotropic effects of inhaled propineb dust (Pauluhn \& Rosenbruch, 2003). These effects are believed to be associated with the principal decomposition products of this type of dithiocarbamate in the biological environment, namely, carbon disulfide and zinc. Exposure to most metals results in metal accumulation in certain tissues and organs of the exposed organisms. It is also known that metals may cause extensive damage to the organs where they accumulate. Zinc $(\mathrm{Zn})$ concentrations vary widely in different tissues, but $\mathrm{Zn}$ is well known to accumulate in two particular organs, namely liver and kidney, where they may cause biochemical and histopathological changes (Goyer, 1986; Wlostowski, 1992; Deveci et al., 1999). The nasal mucosa is a structurally and functionally complex organ in the upper respiratory tract. It is the primary site of entry for inhaled air in the respiratory system of mammals and therefore has many important and diverse functions). Persons with impaired respiratory function, airway diseases and conditions such as emphysema or chronic bronchitis, may incur further disability if excessive concentrations of particulate are inhaled (Santa Cruz Biotechnology, 2012).

CD34 is a cell surface, sialomucin-like glycoprotein that is expressed on hemopoietic progenitor cells, normal vascular endothelium, and fibroblasts. CD34 is expressed most strongly on primitive hemopoietic cells, and is progressively lost as cells differentiate (Strauss et al., 1986). Airway inflammation in patients with asthma and nasal polyps is characterized by the increased presence of several cell types, including mast cells, lymphocytes, and, in particular, eosinophils (Kanai et al., 1994). The aim of this study was to determine the immunohistochemical and histopathological changes on the nasal mucosa after propineb application.

* Department of Otorhinolaryngology, Head and Neck Surgery, Academy of Hospital, Diyarbakır, Turkey.

** Department of Otorhinolaryngology, Head and Neck Surgery, Education Research Hospital of Ankara, Turkey.

*** Department of Otorhinolaryngology, Head and Neck Surgery, Education Research Hospital of Selahaddin Eyyubi, Diyarbakır, Turkey.

**** Department of Otorhinolaryngology, Head and Neck Surgery, Ersoy Hospital, Istanbul, Turkey.

${ }^{* * * * * *}$ Department of Histology and Embryology, School of Medicine, University of Dicle, Diyarbakır, Turkey. 


\section{MATERIAL AND METHOD}

This study was carried out on 20 WistarAlbino rats. These rats, weighing 180-210 g, maintained in standard laboratory conditions at the Department of Medical Science and Research Centre of Dicle University (DUSAM). The animals were group-housed (10 per cage) under standard conditions $\left(21 \pm 2{ }^{\circ} \mathrm{C}\right)$ in the Animal Health and Research Center of Dicle University (DUSAM). The animals had free access to standard laboratory rat pellet and water. They were divided into two groups. The experimental group $(n=10)$ received propineb with spray (obtained Bayer) at a concentration of $400 \mathrm{ppm}$ (ppm/mg toxicant per $1 \mathrm{~kg}$ body weight) in $5 \mathrm{~mL}$ distilled water five days a week (total treatment time was three weeks). Acute oral LD50 for male rats has been found to be $8,500 \mathrm{mg} / \mathrm{kg}$ (Worthing et al., 1983). For application of propineb, rats of experimental group were placed into a glass vase. Propineb was achieved by squeezing of maneb spray inside it. Animals were kept in the glass vase for $1 \mathrm{~h}$. At non-exposure times, rats were kept in laboratory animal house, which was far from the place of exposure with no propineb detection. The control group ( $\mathrm{n}=$ 10) received distilled water with spray. At the end of the study, the animals were sacrificed by decapitation under ether anesthesia. The skins were removed as well as all the soft tissues surrounding the nasal cavity. Then, the bony framework of the nasal cavity including nasal septum were nibbled out by bone-nibbler. The samples were fixed with $10 \%$ formalin solution and decalcified with $5 \%$ EDTA (Ethylene-diaminetetraacetic acid). After preservation, specimens were directly dehydrated in a graded series of ethanol and embedded into paraffin wax. Thin sections, 5-6 micrometres, were cut using a microtome (Rotatory Microtome, Leica, RM 2265, Germany) and stained with Toluidin blue.

Immunohistochemical technique. Immunostaining was carried out using the avidin-biotin-peroxidase complex method. After deparaffinization and dehydration, endogenous peroxidase activity was blocked using three percent hydrogen peroxide in pure methanol for ten minutes at room temperature. The tissues were then treated with 0.01 $\%$ pepsin in $0.01 \mathrm{M} \mathrm{HCl}$ at $37{ }^{\circ} \mathrm{C}$ for $15 \mathrm{~min}$. After serum blocking, using two percent bovine serum albumin, the sections were then incubated with the primary antibody for $30 \mathrm{~min}$ at room temperature. The primary antibody was a mouse monoclonal antibody for low molecular weight cytokeratin at a dilution of one in 40 . This was then incubated using the secondary antibody CD34 for $30 \mathrm{~min}$. Sections were deparaffinized with xylene, followed by immersion in graded acohol for dehydration and incubation with EDTA (pH:8.0, Merck, Germany) for $5+4+3$ min in a microwave oven $(750 \mathrm{~W})$ for antigen retrieval. Next, sections were incubated for $20 \mathrm{~min}$ in $3 \% \mathrm{H}_{2} \mathrm{O}_{2} /$ Methanol to block endogenous peroxidase activity, then rinsed in phosphatebuffered saline (PBS) for 5 min three times. The sections were later incubated with a blocking solution (normal goat serum, Invitrogen, Carlsbad, CA). Slides were then incubated overnight with primary antibodies, Proliferating Cell Nuclear Antigen (PCNA) monoclonal antibody from Labvision Inc., Fremont, CA, USA. After washing in PBS, the sections were treated with labeled-streptavidin kits (Invitrogen, Carlsbad, CA). The reaction was visualized by incubating the sections for $7 \mathrm{~min}$ in a $0.1 \% 3,3$ diaminobenzidine and $0.02 \%$ hydrogen peroxide solution (DAB substrate kit, Invitrogen, Carlsbad CA). Finally, the sections were counterstained with Hematoxylin (Sigma) and covered. Immunohistochemistry positive staining was defined as the presence of a brown color detection chromogen (DAB) on the edge of the hematoxylin-stained cell nucleus distributed within the cytoplasm or plasma membrane of the cells and assessed by light microscope.

Statistical Analysis. Statistical analysis was performed with the Statistical Package for the Social Sciences for Windows (version 15.0, SPSS Inc.,Chicago, IL, USA). The MannWhitney U test was used for the statistics as indicated, test and results were expressed as Mean \pm SD. P values below 0.05 were considered to indicate statistical significance.

\section{RESULTS}

There were no any histopathological changes in control group sections of nasal mucosa. Normal characteristic features of nasal mucosa were viewed in control group, whereas in experimental group, some changes were observed in nasal mucosa (Table I).

Degenerative changes in epithelium were observed in sections of propineb-treated group. A number of inflammatory cells were also observed in propineb-treated group. Immunohistochemical with respect to CD34 expression, there was a remarkable difference between nicotine treated and non-treated group. Dark brown color of endothelial cells indicates positive staining for CD34 in vessel endothelium of connective tissue. In the group treated with propineb PCNA positive reaction in the respiratory epithelium, the lamina propria layer was observed in the deeper layers and subepithelial mast cells. PCNA-positive cells were observed as discrete along the basement membrane. PCNA positive reaction significant and positive nuclei in the apical portion of ciliated respiratory epithelium was seen near the basement membrane. 
Table I. Comparison of propineb and control groups by means of PCNA, CD34 antibody expressions and histopathological features.

\begin{tabular}{lccc}
\hline & $\begin{array}{r}\text { Control group } \\
(\mathbf{n}=\mathbf{1 0})(\mathbf{M e a n} \pm \mathbf{S D})\end{array}$ & $\begin{array}{r}\text { Propineb group } \\
(\mathbf{n = 1 0})(\mathbf{M e a n} \pm \mathbf{S D})\end{array}$ & $\mathbf{P}$ \\
\hline Epithelial Degeneration & $0.0 \pm 0.0$ & $3.01 \pm 0.51$ & $\leq 0.001$ \\
PCNA ex pression & $0.23 \pm 0.40$ & $3.03 \pm 0.50$ & $<0.01$ \\
CD34 expression & $0.32 \pm 0.52$ & $3.23 \pm 0.52$ & $<0.01$ \\
Leukocyte infiltration & $0.22 \pm 0.43$ & $3.13 \pm 0.50$ & $<0.01$ \\
\hline
\end{tabular}

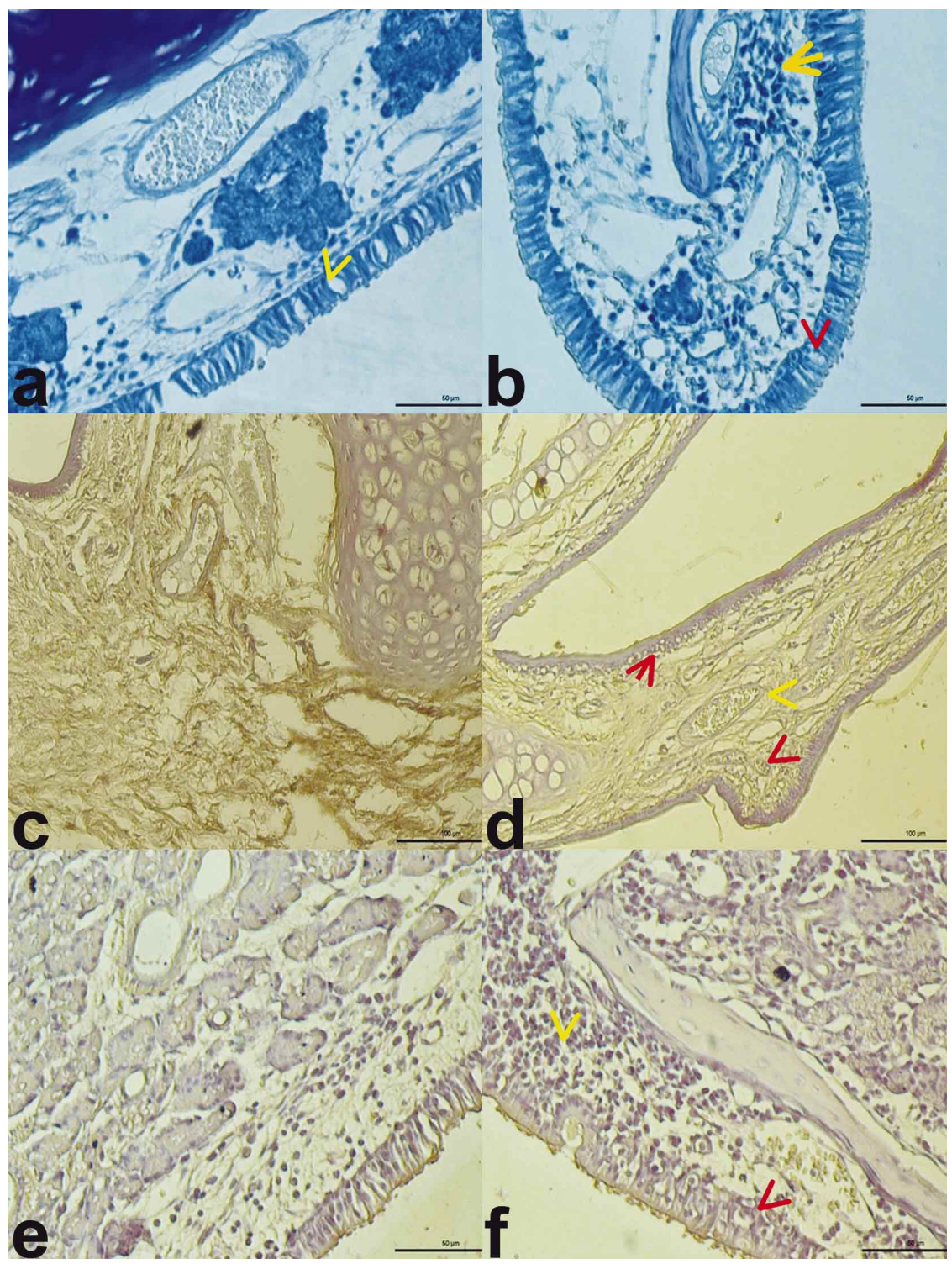

Fig. 1. Epithelial and goblet cells (arrow) and connective tissue of nasal mucosa appear normal in non-treated group sections. (a) Degeneration in basal cells (red arrow), leukocyte infiltration (yellow arrow) and dilatation in vessels. (b) Toluidin Blue stain Bar $50 \mu \mathrm{m}$, Control group; Immunohistochemical localization of CD34 in nasal mucosa. (c) Diffuse immunoreactive CD34 positive expression of leukocyte cells (red arrow and endothelial cells in the lamina propria (yellow arrow). (d) CD34 immunostaining Bar $50 \mu \mathrm{m}$,Control group; Negative PCNA expression in basal cells and connective tissue cells. (e) Positive expression of PCNA in degenerative nucleus along the basement membrane (red arrow)High expression of PCNA in leukocyte cells and mast cells of lamina propria (yellow arrow). (f) PCNA immuno staining Bar $50 \mu \mathrm{m}$. 


\section{DISCUSSION}

Propineb has a low acute toxicity with a specific goitrogenic effect in rats. In repeated-dose toxicological studies, in addition to effects on the thyroid gland, reversible effects on skeletal muscles were described (Branch et al. 1996; IPCS, 1993, 1998). Srivastava et al. (2012) also determined that mancozeb (it is a combination of Zinc and maneb) exposure can induce genotoxicity and apoptosis in cultured human lymphocytes.

Propineb in the nasal inhalation study in rats, at least lung uncertain pathophysiological significance and impact of the hind leg muscle weakness (Pauluhn \& Rosenbruch) have been identified. Nasal cavity has a mucosal surface and lined with the columnar epithelium that lines the airways of the lung. This mucosal surface of nasal cavity covered with a rich vascular bed. Nasal surface may be affected from both inhalants in the air and agents in the circulation. The inhalation of toxic gases ingested chemicals can also affect the respiratory mucosa. The rat nasal mucosa was selected for this experimental toxic agent inhalation study as potentially affected part of respiratory system. It is well known that the numbers of inflammatory cells such as eosinophils are increased in the airways in such chronic airway inflammatory conditions as bronchial asthma (Gibson et al.). Deveci et al. (2013) demonstrated that a maneb (it is a kind of dithiocarbamade fungicide) inhalation may cause respiratory epithelium degeneration in rats. The dithiocarbamates have been known to cause some upper and lower airway symptoms in humans, i.e. rhinitis, pharyngitis, and bronchitis (Israeli et al., 1983). However, there is report of histopathologic findings in nasal mucosa induced by maneb. In a study, stated that prevent encephalopathy and brain development through the placental barrier propineb (Ekinci et al., 2014). In our study, the turbinate mucosa degeneration depending on propineb effects have been exposed to vascular injury and inflammation. This is a result of inhalation of the situation ethmoidal hole is thought to affect the brain tissue.

The expression of CD34 is not restricted to hemopoietic progenitor cells, but has also been detected by immunohistochemical analysis on vascular endothelium of normal and neoplastic tissues (Delia et al., 1993; Norton et al., 1993). We detected CD34-immunoreactive mononuclear cells and endothel cells in the lamina propria of propineb group. CD34 plays an important role in cytokine mediated leukocyte adhesion and inflammation. You may also adversely affect the adhesive properties of endothelial cells. In humans, PCNA-positive MCs have been observed in the nasal sub-epithelial and lamina propria layers in patients suffering allergic rhinitis (Otsuka et al., 1998). A proliferation of mature MCs has also been reported in the nasal mucosa of those suffering allergies (Tsai et al., 1991; Bischoff et al., 1999). In the current study, a high number of PCNApositive cells were seen in the sub-epithelial layer and deep lamina propria. As a result of inhalation in rats propineb, allergic rhinitis nasal mucosa by increasing the reaction was considered significant impact.

SAMANCI, B.; ARSLAN, E.; SAMANCI, S. B.; CAYPINAR, B.; DEVECI, E.; SÖKER, S. \& SEKER, U. Efectos de los polímeros del zinc propileno-bis-ditiocarbamato (Propineb) en la mucosa nasal de ratas. Int. J. Morphol., 34(1):85-89, 2016.

RESUMEN: El objetivo de este estudio fue evaluar los efecto histopatológicos e inmunohistoquímicos del Propineb en la mucosa nasal de 20 ratas Sprague-Dawley adultas con un peso de 180-220 g, las que fueron utilizadas como animales de experimentación. Las ratas se dividieron en grupos Propineb y Control. El grupo control recibió agua destilada en aerosol nasal en el mismo período de tiempo que el grupo Propineb. El experimento duró tres semanas. Posteriormente, en cada caso se tomaron muestras de la mucosa nasal. En el grupo experimental, tratado con Propineb, el examen microscópico de la mucosa respiratoria nasal reveló cambios degenerativos en el epitelio. Se detectó también infiltración de leucocitos y dilatación vascular en el tejido conectivo, junto con células mononucleares CD34 inmunorreactiva y células endoteliales en la lámina propia. En el grupo Propineb, en comparación con el grupo control, los núcleos de la porción respiratoria, las células caliciformes y basales resultaron positivas a la tinción del antígeno nuclear de proliferación celular (PCNA). La inhalación de Propineb puede ser un irritante para la mucosa nasal.

PALABRAS CLAVE: Propineb; Mucosa nasal; Antígeno nuclear de proliferación celular (PCNA); CD34.

\section{REFERENCES}

Bischoff, S. C.; Sellge, G.; Lorentz, A.; Sebald, W.; Raab, R. \& Manns, M. P. IL-4 enhances proliferation and mediator release in mature human mast cells. Proc. Natl. Acad. Sci. USA, 96(14):8080-5, 1999. 
Branch, S.; Rogers, J. M.; Brownie, C. F. \& Chernoff, N. Supernumerary lumbar rib: manifestation of basic alteration in embryonic development of ribs. J. Appl. Toxicol., 16(2):1159, 1996.

Delia, D.; Lampugnani, M. G.; Resnati, M.; Dejana, E.; Aiello, A.; Fontanella, E.; Soligo, D.; Pierotti, M. A. \& Greaves, M. F. CD34 expression is regulated reciprocally with adhesion molecules in vascular endothelial cells in vitro. Blood, 81(4):1001-8, 1993.

Deveci, E.; Guven, K.; Bashan, M.; Onen, A. \& de Pomerai, D. The accumulation and histological effects of organometallic fungicides propineb and maneb in the livers of pregnant rats and their offspring. J. Toxicol. Sci., 24(2):79-85, 1999.

Deveci, E.; Yorgancilar, E.; Ekinci, C.; Koparal, M.; Akkus, Z. \& Yavuz, D. Effects of manganase ethylene-bis-dithiocarbomate (maneb) on rat nasal mucosa. Acta Med. Mediterr., 29:875-8, 2013.

Ekinci, C.; Tahaoglu, A. E.; Yavuz, D.; Deveci, E.; Aktas, A.; Yilmaz, T.; Yumusak, Ö. \& Yükselmis, O. Ultrastructural effects of the Propineb on brain of fetuses during rat pregnancy. Int. J. Morphol., 32(4):1467-71, 2014.

Gibson, P. G.; Girgis-Gabardo, A.; Morris, M. M.; Mattoli, S.; Kay, J. M.; Dolovich, J.; Denburg, J. \& Hargreave, F. E. Cellular characteristics of sputum from patients with asthma and chronic bronchitis. Thorax, 44(9):693-9, 1989.

Goyer, R. Toxic Effects of Metals. In: Klaassen, C. D.; Amdur, M. O. \& Doull, J. (Eds.). Casarett \& Doull's Toxicology: The Basic Science of Poisons. New York, Macmillan, 1986. pp.623-80.

International Programme on Chemical Safety (IPCS). Propineb. In: Pesticide residues in food: 1993 evaluations Part II Toxicology). 1993. Available from: http://www.inchem.org/ documents/jmpr/jmpmono/v93pr16.htm

International Programme on Chemical Safety (IPCS). Dithiocarbamate pesticides, ethylenthiourea and propilenthiourea: a general introduction. Environmental Health Criteria 78, 1998. Available from: http:// www.inchem.org/documents/ehc/ehc/ehc78.htm

Israeli, R.; Sculsky, M. \& Tiberin, P. Acute intoxication due to exposure to maneb and zineb. A case with behavioral and central nervous system changes. Scand. J. Work Environ. Health, 9(1):47-51, 1983.

Kanai, N.; Denburg, J.; Jordana, M. \& Dolovich, J. Nasal polyp inflammation. Effect of topical nasal steroid. Am. J. Respir. Crit. Care Med., 150(4):1094-100, 1994.

Norton, J.; Sloane, J. P.; Delia, D. \& Greaves, M. F. Reciprocal expression of CD34 and cell adhesion molecule ELAM-1 on vascular endothelium in acute cutaneous graft-versus-host disease. J. Pathol., 170(2):173-7, 1993.
Otsuka, H.; Kusumi, T.; Kanai, S.; Koyama, M.; Kuno, Y. \& Takizawa, R. Stem cell factor mRNA expression and production in human nasal epithelial cells: contribution to the accumulation of mast cells in the nasal epithelium of allergy. J. Allergy Clin. Immunol., 102(5):757-64, 1998.

Pauluhn, J. \& Rosenbruch, M. Inhalation toxicity of propineb. Part I: Results of subacute inhalation exposure studies in rats. Inhal. Toxicol., 15(5):411-34, 2003.

Santa Cruz Biotechnology. Propineb sc-229002. Material Safety Data Sheet. Santa Cruz, California, Santa Cruz Biotechnology, 2012. Available from: http://datasheets.scbt.com/sds/WPNA/ EN/sc-229002.pdf

Srivastava, A. K.; Ali, W.; Singh, R.; Bhui, K.; Tyagi, S.; AlKhedhairy, A. A.; Srivastava, P. K.; Musarrat, J. \& Shukla, Y. Mancozeb-induced genotoxicity and apoptosis in cultured human lymphocytes. Life Sci., 90(21-22):815-24, 2012.

Strauss, L. C.; Rowley, S. D.; La Russa, V. F.; Sharkis, S. J.; Stuart, R. K. \& Civin, C. I. Antigenic analysis of hematopoiesis. V. Characterization of My-10 antigen expression by normal lymphohematopoietic progenitor cells. Exp. Hematol., 14(9):878-86, 1986.

Tsai, M.; Takeishi, T.; Thompson, H.; Langley, K. E.; Zsebo, K. M.; Metcalfe, D. D.; Geissler, E. N. \& Galli, S. J. Induction of mast cell proliferation, maturation, and heparin synthesis by the rat c-kit ligand, stem cell factor. Proc. Natl. Acad. Sci. USA, 88(14):6382-6, 1991.

Wostowski, T. On metallothionein, cadmium, copper and zinc relationships in the liver and kidney of adult rats. Comp. Biochem. Physiol. C, 103(1):35-41, 1992.

Worthing, C. R.; Walker, S. B. \& British Crop Protection Council. The Pesticide Manual: A World Compendium. Croydon, British Crop Protection Council, 1983.

\section{Correspondence to:}

Prof. Dr. Engin Deveci

Department of Histology and Embryology

School of Medicine

Dicle University

Diyarbakir

TURKEY

Email: engindeveci64@gmail.com

Received: 24-03-2015

Accepted: 04-11-2015 